\title{
DNA barcoding of shared fish species from the North Atlantic and Australasia: minimal divergence for most taxa, but Zeus faber and Lepidopus caudatus each probably constitute two species
}

\author{
Robert D. Ward ${ }^{1, *}$, Filipe O. Costa ${ }^{2}$, Bronwyn H. Holmes ${ }^{1}$, Dirk Steinke ${ }^{3}$ \\ ${ }^{1}$ CSIRO Wealth from Oceans Flagship, CSIRO Marine and Atmospheric Research, GPO Box 1538, Hobart, Tasmania, Australia \\ ${ }^{2}$ Molecular Ecology and Fisheries Genetics Laboratory, School of Biological Sciences, Environment Centre Wales, \\ Bangor University, Bangor, Gwynedd LL57 2UW, UK \\ ${ }^{3}$ Canadian Centre for DNA Barcoding, Biodiversity Institute of Ontario, University of Guelph, 579 Gordon Street, Guelph, \\ Ontario N1G 2W1, Canada
}

\begin{abstract}
Fifteen fish species, totalling 149 specimens, were cytochrome $c$ oxidase I sequencedbarcoded - from Northern (Atlantic and Mediterranean) and Southern (Australasian) Hemisphere waters. Thirteen species showed no significant evidence of spatial genetic differentiation for this gene, although small sample sizes reduced statistical power. For marine fish, barcodes collected in one part of a species range are likely to be useful as identifiers in all other parts of its range. Two species did show striking north-south differentiation, with $F_{\mathrm{ST}}$ values of 0.84 and 0.96 (both $\mathrm{p} \ll 0.001$ ). One of these, the silver scabbardfish Lepidopus caudatus, showed $2.75 \%$ genetic distance between northern and southern clades. The other, John dory Zeus faber, showed $7.44 \%$ differentiation between northern and southern clades. All specimens of these 2 species fell correctly into the northern or southern clade. We suggest that both taxa conceal a currently unrecognised, cryptic species, and recommend further taxonomic and genetic investigation.
\end{abstract}

KEY WORDS: Mitochondrial DNA $\cdot$ Cytochrome $c$ oxidase $\cdot$ COI $\cdot$ CoxI $\cdot$ Identification $\cdot$ Zeus faber $\cdot$ Lepidopus caudatus · Cryptic species

Resale or republication not permitted without written consent of the publisher

\section{INTRODUCTION}

DNA barcoding - the sequencing of a short standardised region of DNA - has been proposed as a new tool for animal species identification (Hebert et al. 2003). The region nominated, and widely adopted, is a ca. $650 \mathrm{bp}$ region of the 5' end of cytochrome $c$ oxidase I (COI), a mitochondrial DNA locus. This has been shown to provide species level resolution of the vast bulk of species in a wide range of animal taxa, including ants, bats, birds, butterflies, crustaceans, fish, and spiders (Hebert et al. 2004a,b, Barrett \& Hebert 2005, Smith et al. 2005, Ward et al. 2005, Clare et al. 2007, Costa et al. 2007).
The methodology requires that intra-species DNA barcode variation is substantially less than interspecies variation, allowing accurate identification of individuals. One of the criticisms (e.g. Moritz \& Cicero 2004, Dasmahapatra \& Mallet 2006) made of early studies was that samples were generally taken from a narrow geographic region, so that intra-species level variability may well have been markedly underestimated. It is well known that there is extensive population differentiation for many animal taxa, reflecting varying levels of reproductive isolation (Ward et al. 1992). Freshwater fishes show more population differentiation than marine species, although marine species can show significant differentiation (Ward et al. 1994). 
Table 1. Species, sample sizes (N), localities and GenBank accession codes of sequences. Common names are from FishBase (www.fishbase.org)

\begin{tabular}{|c|c|c|c|}
\hline Taxon and Region & $\mathrm{N}$ & Sample localities & GenBank $^{1}$ \\
\hline \multicolumn{4}{|l|}{ Elasmobranchs } \\
\hline \multicolumn{4}{|c|}{ Etmopterus pusillus, Smooth lanternshark } \\
\hline North & 4 & Portugal & EU869807-EU869810 \\
\hline South & 2 & Tasmania, Australia (1), New Zealand (1) & EU398783, P41772 \\
\hline \multicolumn{4}{|c|}{ Heptranchias perlo, Sharpnose sevengill shark } \\
\hline North & 1 & Portugal & EU869819 \\
\hline South & 2 & Western Australia, Australia & EU869817, EU869818 \\
\hline \multicolumn{4}{|c|}{ Isurus oxyrinchus, Shortfin mako } \\
\hline North & 3 & Malta (1), Nova Scotia, Canada (2) & EU869822, 05-622-002f3, 05-620-002d3 \\
\hline \multirow[t]{2}{*}{ South } & 13 & Lombok, Indonesia (5), New South Wales, & EU398889-EU398897 \\
\hline & & Australia (4), New Zealand (4) & MAK9, MAK10, MAK15, MAK16 \\
\hline \multicolumn{4}{|c|}{ Prionace glauca, Blue shark } \\
\hline North & 7 & Malta (1), Nova Scotia, Canada (6) & $\begin{array}{l}\text { EU869837 05-617, 05-605-002e1, 05-607-002g1, } \\
\text { 05-609-002a2, 05-612-002d2, 05-613-002e2 }\end{array}$ \\
\hline South & 6 & Tasmania, Australia (5), New Zealand (1) & DQ108285-DQ108289, BWS3 \\
\hline \multicolumn{4}{|c|}{ Pseudotriakis microdon, False catshark } \\
\hline North & 2 & Mid-Atlantic Ridge & EU148299, EU148300 \\
\hline South & 1 & E Indian Ocean & EU869838 \\
\hline \multicolumn{4}{|c|}{ Squalus acanthias, Piked dogfish } \\
\hline North & 10 & $\begin{array}{l}\text { Gulf of Maine (5), Celtic Sea, UK (4), } \\
\text { Iceland (1) }\end{array}$ & $\begin{array}{l}\text { EF539278-EF539281，EF539287-EF539291， } \\
\text { NC_002012 }\end{array}$ \\
\hline South & 7 & Tasmania, Australia (5), New Zealand (2) & DQ108279-DQ108282, DQ108267, Fe119, P42571 \\
\hline \multicolumn{4}{|l|}{ Teleosts } \\
\hline \multicolumn{4}{|c|}{ Halargyreus johnsonii, Slender codling } \\
\hline North & 1 & Mid-Atlantic Ridge & EU148182 \\
\hline South & 5 & Tasmania, Australia & EU869811-EU869815 \\
\hline \multicolumn{4}{|c|}{ Halosauropsis macrochir, Abyssal halosaur } \\
\hline North & 3 & Mid-Atlantic Ridge & EU148183-EU148185 \\
\hline South & 1 & Tasman Sea, Australia & EU869816 \\
\hline \multicolumn{4}{|c|}{ Hoplostethus atlanticus, Orange roughy } \\
\hline North & 3 & Mid-Atlantic Ridge & EU148195-EU148197 \\
\hline South & 6 & Tasmania, Australia (5), New Zealand (1) & DQ108109-DQ108113, P41334 \\
\hline \multicolumn{4}{|c|}{ Hoplostethus mediterraneus, Mediterranean slimehead } \\
\hline North & 2 & Portugal & EU869820, EU869821 \\
\hline \multirow[t]{2}{*}{ South } & 9 & Tasmania, Australia (5), New Zealand (4) & DQ885093, DQ108089-DQ108092 \\
\hline & & & P39186, P39159, Р395918, Р39213 \\
\hline \multicolumn{4}{|c|}{ Lepidopus caudatus, Silver scabbardfish } \\
\hline North & 6 & Portugal & EU869827-EU869832 \\
\hline South & 8 & $\begin{array}{l}\text { New South Wales, Australia (4), } \\
\text { New Zealand (4) }\end{array}$ & EU869823-EU869826, FRO1-FRO4 \\
\hline \multicolumn{4}{|c|}{ Neocyttus helgae, False boarfish } \\
\hline North & 5 & Faeroes, Denmark (2), Mid-Atlantic Ridge (3) & DQ108079, DQ108080, EU148263-EU148265 \\
\hline South & 4 & SW Indian Ocean & EU869833-EU869836 \\
\hline \multicolumn{4}{|c|}{ Sphoeroides pachygaster, Blunthead puffer } \\
\hline North & 3 & Portugal & EU869841-EU869843 \\
\hline South & 2 & $\begin{array}{l}\text { Tasman Sea, Australia (1), Western } \\
\text { Australia (1) }\end{array}$ & EU869840, EU869839 \\
\hline \multicolumn{4}{|c|}{ Tetragonurus cuvieri, Smalleye squaretail } \\
\hline North & 3 & Mid-Atlantic Ridge & EU148348-EU148350 \\
\hline South & 3 & $\begin{array}{l}\text { New South Wales, Australia (1), } \\
\text { SW Indian Ocean (1), New Zealand (1) }\end{array}$ & DQ107601, DQ107616, P42399 \\
\hline \multicolumn{4}{|c|}{ Zeus faber, John dory } \\
\hline North & 22 & Portugal (15), Celtic Sea, UK (3), Malta (4) & EU869849-EU869870 \\
\hline South & 11 & $\begin{array}{l}\text { Victoria, Australia (4), Western Australia, } \\
\text { Australia (2), New Zealand (5) }\end{array}$ & $\begin{array}{l}\text { EF609496, EU869844-EU869848 } \\
\text { JDO1-JDO5 }\end{array}$ \\
\hline
\end{tabular}


We assess the intra-species barcode variability for 15 species of marine fishes sampled from opposite sides of the world. The primary objective was to see if, for this group of taxa, barcoding is indeed an effective species identification tool on a global scale.

\section{MATERIALS AND METHODS}

Collection. Fishes were sampled from both northern and southern waters, with an average distance between the 2 regions of around $23000 \mathrm{~km}$. Fishes were collected from the North Atlantic (off Nova Scotia, Portugal, the Southwest United Kingdom, and from the midAtlantic Ridge) and the Mediterranean Sea. These are subsequently collectively referred to as north samples. Fish were also collected from Australian and New Zealand waters and adjacent Indian Ocean sites. These are collectively referred to as south samples. Fifteen species were collected from both north and south regions, with a total sample size of 149 specimens (Table 1). Many of these specimens exist as whole-animal vouchers in the Australian Museum (Sydney, Australia), Australian National Fish Collection (Hobart, Australia), Bergen Museum (Bergen, Norway), Museu Bocage (Lisbon, Portugal), Museum Te Papa (Wellington, New Zealand) and Museum Victoria (Melbourne, Australia). More details can be found in BOLD (Barcode of Life Database, www. barcodinglife.org) and GenBank (www.ncbi.nlm.nih. gov), using the reference numbers in Fig. 1 and Table 1.

Sequencing. Specimens were sequenced for an approximately $650 \mathrm{bp}$ region of the mitochondrial gene cytochrome $c$ oxidase following Ward et al. (2005) or Ivanova et al. (2007). For most specimens, the tissue source was white muscle; for a few, finclips were used. The barcode of 1 specimen, a Squalus acanthias, came from GenBank (NC_002012). Average sequence length was $646.6 \mathrm{bp}$, ranging from 549 to $654 \mathrm{bp}$. No indels or stop codons were recorded. Sequence data were aligned using Sequencing Analysis v.5.1 and SeqScape v.2.5 (Applied Biosystems). Sequence data were submitted to BOLD (Ratnasingham \& Hebert 2007) and to GenBank.

Analysis of genetic differentiation. Sequence divergence values, hereafter referred to as distance or $D$, within and between species were calculated in MEGA
3.1 (Kumar et al. 2004), using the Kimura 2-parameter (K2P) distance model (Kimura 1980). Neighbour-joining trees were estimated using MEGA v.3.1, with the pairwise deletion of missing nucleotide data option: these were bootstrapped 1000 times to provide percentage bootstrap values for branch points. Standard errors of $D$ were similarly estimated in MEGA v.3.1, from 500 bootstrapped values. Neighbour-joining trees and bootstrapped values utilising the maximum composite likelihood method (Tamura et al. 2004) were essentially identical to the K2P trees. The $F_{\mathrm{ST}}$ values for pairwise comparisons of north versus south populations of each species were estimated from information on both haplotype frequency and extent of divergence (Nei's pairwise differences), using AMOVA in the software Arlequin v. 3.1 (Excoffier et al. 2005). We applied 16000 permutations to test the significance of $F_{\mathrm{ST}}$ values. 


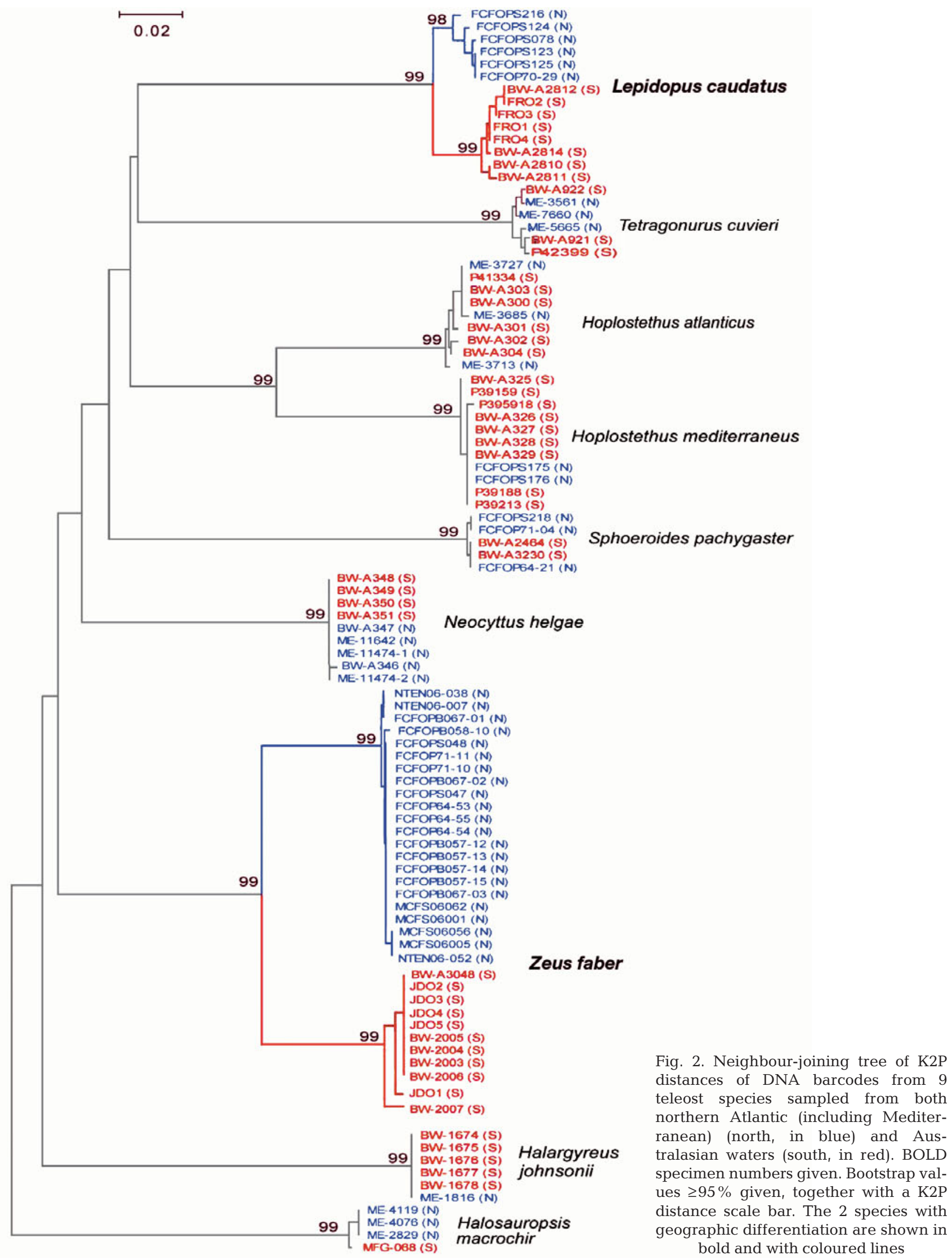


Samples from each of the 15 species were categorised as north or south (Table 1). The genetic distance among and within the specimens of each geographic group and species was estimated, as was the extent of spatial genetic differentiation $\left(F_{\mathrm{ST}}\right)$ between groups.

\section{RESULTS}

Neighbour-joining trees for the 6 elasmobranch and 9 teleost species are provided in Figs. 1 \& 2, respectively. Two species (Pseudotriakis microdon and Halargyreus johnsonii) showed zero divergence between north and south groups. However, as each of these species had only a single representative for 1 of the 2 groups, additional sampling might uncover variability. Nine species showed between 0 and $1 \%$ north to south (N-S) divergence (Etmopterus pusillus, Prionace glauca, Squalus acanthias, Halosauropsis macrochir, Hoplostethus atlanticus, Hoplostethus mediterraneus, Neocyttus helgae, Sphoeroides pachygaster and Tetragonurus cuvieri). This inter-group divergence generally approximated the amount of within-north or within-south divergence, emphasising the lack of clear-cut spatial differentiation for these species. Two species showed between 1 and $2 \% \mathrm{~N}-\mathrm{S}$ divergence. One of these, Isurus oxyrinchus, showed $1.04 \%$ divergence. However, this barcode-variable species showed as much divergence within both the south and north groups; there is no evidence of spatial genetic differentiation. The other, Heptranchias perlo, was only represented by 3 specimens and had a $\mathrm{N}-\mathrm{S}$ divergence of $1.72 \%$. The 2 samples from the south had an identical haplotype, but more samples are required to deter- mine whether this apparent N-S differentiation reflects real genetic isolation or is simply a sampling artefact.

The final 2 species, both teleosts (Fig. 2), show very striking N-S differentiation. Lepidopus caudatus, despite typical levels of within-region differentiation ( 0.54 and $0.43 \%$ for the north and south, respectively), shows a high $2.75 \%$ average differentiation between the north and south. Zeus faber shows lower amounts of within-region differentiation ( 0.20 and $0.23 \%$ ), but an extremely high $7.39 \%$ average between the north and south.

The $F_{\mathrm{ST}}$ results (Table 2) accorded with the above observations. The only 2 species to show statistically significant N-S differentiation were Lepidopus caudatus and Zeus faber, with the extremely high $F_{\mathrm{ST}}$ values of 0.84 and 0.97 , respectively, both with probabilities of $<0.001$. Two other species had very high $F_{\mathrm{ST}}$ values, Heptranchias perlo and Halosauropsis macrochir. In both these cases the $F_{\mathrm{ST}}$ value was 1 , but, in both, 1 geographic group was only represented by a single specimen and the $F_{\mathrm{ST}}$ value was not significantly different from zero. Further sampling of these 2 species is required.

The neighbour-joining tree of distance (Fig. 1) supports the lack of significant differentiation of north and south specimens for 12 of the 15 species. The 2 south specimens of Heptranchias perlo separate at a $99 \%$ bootstrap value from the single north specimen, but whether this is meaningful or not requires further sampling. In accord with the preceding findings, Lepidopus caudatus separates clearly into a north clade and a south clade, with 98 and $99 \%$ bootstrap support, respectively. Even more strikingly, Zeus faber separates into 2 deeply divergent clades, north and south,

Table 2. Extent of genetic divergence within and between northern Atlantic (including Mediterranean) (north) and Australasian (south) groups of each of 15 fish species. Mean $( \pm \mathrm{SE}) \mathrm{K} 2 \mathrm{P}$ distance and $F_{\mathrm{ST}}$ (with probability of no divergence) between north and south groups

\begin{tabular}{|lcccrrr}
\hline Taxon & North & South & North-South & Overall & $F_{\text {ST }}$ & p \\
\hline Etmopterus pusillus & $0.193 \pm 0.130$ & $0.365 \pm 0.250$ & $0.313 \pm 0.154$ & $0.269 \pm 0.126$ & 0.178 & 0.264 \\
Heptranchias perlo & - & $0.000 \pm 0.000$ & $1.721 \pm 0.511$ & $1.147 \pm 0.339$ & 1.000 & 0.332 \\
Isurus oxyrinchus & $1.048 \pm 0.324$ & $1.062 \pm 0.259$ & $1.043 \pm 0.258$ & $1.055 \pm 0.249$ & -0.040 & 0.529 \\
Prionace glauca & $0.088 \pm 0.058$ & 0.000 & $0.045 \pm 0.030$ & $0.048 \pm 0.031$ & -0.024 & 1.000 \\
Pseudotriakis microdon & 0.000 & - & 0.000 & 0.000 & 0.000 & 1.000 \\
Squalus acanthias & $0.154 \pm 0.067$ & $0.088 \pm 0.057$ & $0.121 \pm 0.045$ & $0.127 \pm 0.0470$ & -0.012 & 0.819 \\
Halargyreus johnsonii & - & 0.000 & 0.000 & 0.000 & 0.000 & 1.000 \\
Halosauropsis macrochir & 0.000 & - & $0.308 \pm 0.022$ & $0.154 \pm 0.112$ & 1.000 & 0.246 \\
Hoplostethus atlanticus & $0.515 \pm 0.222$ & $0.495 \pm 0.213$ & $0.455 \pm 0.168$ & $0.477 \pm 0.183$ & -0.108 & 0.616 \\
Hoplostethus mediterraneus & $0.308 \pm 0.219$ & $0.262 \pm 0.104$ & $0.281 \pm 0.116$ & $0.274 \pm 0.089$ & -0.085 & 0.509 \\
Lepidopus caudatus & $0.542 \pm 0.169$ & $0.434 \pm 0.160$ & $2.749 \pm 0.539$ & $1.673 \pm 0.321$ & 0.835 & $<0.001$ \\
Neocyttus helgae & $0.062 \pm 0.061$ & $0.077 \pm 0.074$ & $0.069 \pm 0.048$ & $0.068 \pm 0.046$ & -0.154 & 1.000 \\
Sphoeroides pachygaster & $0.103 \pm 0.097$ & $0.154 \pm 0.150$ & $0.180 \pm 0.122$ & $0.154 \pm 0.105$ & 0.323 & 0.297 \\
Tetragonurus cuvieri & $0.746 \pm 0.276$ & $0.514 \pm 0.227$ & $0.614 \pm 0.201$ & $0.620 \pm 0.211$ & -0.029 \\
Zeus faber & $0.204 \pm 0.078$ & $0.230 \pm 0.078$ & $7.386 \pm 1.095$ & $3.499 \pm 0.515$ & 0.974 & $<0.001$ \\
\hline
\end{tabular}


each with $99 \%$ bootstrap support. Finally, while there is evidence of 2 Isurus oxyrinchus clades (Fig. 1; see also Ward et al. 2008), these do not appear to be differentiated geographically. These 2 clades separate by $1.66 \%$ and have bootstrap values of 55 and $87 \%$.

\section{DISCUSSION}

There are about 300 fish species that are shared between the North Atlantic (FAO Fishing Area 27) and Australasian southern waters (FAO 57 and FAO 81) (N. Bailly pers. comm.). Here, we have examined 15 of these species, 13 of which do not show statistically significant evidence of spatial genetic differentiation despite the enormous geographic distances separating populations. While we accept that samples for some species are very small, we nevertheless contend that the results show that barcoding can work as a global species identifier for marine fish species. DNA barcodes collected in one part of a marine fish's range are likely to be useful as identifiers in all other parts of the species' range. For these species, limited regional sampling is unlikely to negate or fundamentally diminish the utility of the barcode methodology in other parts of the species' range (cf. Moritz \& Cicero 2004, Dasmahapatra \& Mallet 2006). The generality of this conclusion and extension to other taxa requires further investigation-marine fish are known to show low average amounts of population differentiation compared with, for example, freshwater fish (Ward et al. 1994).

A few earlier genetic studies also noted a lack of differentiation between northern and southern populations of some marine fishes. One of the species barcoded here, Hoplostethus atlanticus (orange roughy), showed only $0.18 \%$ divergence between 77 Australian specimens and 96 North Atlantic specimens in a mtDNA RFLP study (Elliott et al. 1994, also see Smith 1986). The similarly deep-sea Beryx cf. splendens sp. A showed very little mtDNA differentiation between the Northeast Atlantic and Southwest Pacific (Hoarau \& Borsa 2000). However, genetic homogeneity, or nearhomogeneity, between the North Atlantic and Australasia is not restricted to deep-sea fishes. While 9 of the 13 species not showing significant $F_{\mathrm{ST}}$ differentiation are indeed deep-water or demersal species (Etmopterus pusillus, Halargyreus johnsonii, Halosauropsis macrochir, Heptranchias perlo, Hoplostethus atlanticus, Neocyttus helgae, Pseudotriakis microdon, Sphoeroides pachygaster, Tetragonurus cuvieri), 2 are benthopelagic (Hoplostethus mediterraneus, Squalus acanthias) and 2 are epipelagic (Isurus oxyrinchus, Prionace glauca). Perhaps the lack of differentiation for the deep-water and demersal species reflects current or recent gene flow among a connected series of populations on oceanic ridges or continental slopes. On the other hand, I. oxyrinchus (shortfin mako) and $P$. glauca (blue shark) are both known to be highly migratory (Clarke \& Stevens 1974, Casey \& Kohler 1992, Campana et al. 2005, Queiroz et al. 2005), and this probably accounts for their lack of appreciable spatial differentiation. Two of these 13 species (Heptranchias perlo, Halosauropsis macrochir) show some evidence of possible population differentiation, but small sample sizes made this statistically non-significant. However, it must be stressed that COI is a relatively conserved gene within fishes, and most of the above species show low levels of intraspecific variation; a more variable gene such as the mtDNA d-loop region (or microsatellite loci) may well show heightened levels of population differentiation and provide a better indicator of genetic connectivity.

Lepidopus caudatus, the silver scabbardfish, shows very clear geographic differentiation, with 1 clade in the north and 1 in the south and no shared haplotypes. The extent of $\mathrm{N}-\mathrm{S}$ differentiation, an average of $2.75 \%$, is 5 to 6 times that found among either the north or the south groups. Four specimens from South African waters cluster very tightly with the Australasian representatives (Fig. 3).

Zeus faber, the John dory, shows still more differentiation. The north and south clades again share no haplotypes, and the $\mathrm{N}-\mathrm{S}$ differentiation, at $7.39 \%$, is about 35 -fold that within the north or south groups. A single specimen barcoded from South Africa clusters very tightly with Australasian specimens (Fig. 4).

The marked levels of N-S differentiation for these 2 species, especially in conjunction with the lack of differentiation observed in the other fish species, may indicate cryptic speciation. Surveys of several hundred fish species (Ward et al. 2005, 2008, Rock et al. 2008) show that the average degree of intraspecific differentiation for the COI barcode region is around $0.4 \%$, with $>90 \%$ of cases showing $<1 \%$ differentiation. The average degree of overall differentiation for the 15 species examined here is about $0.6 \%$, falling to about $0.3 \%$ if

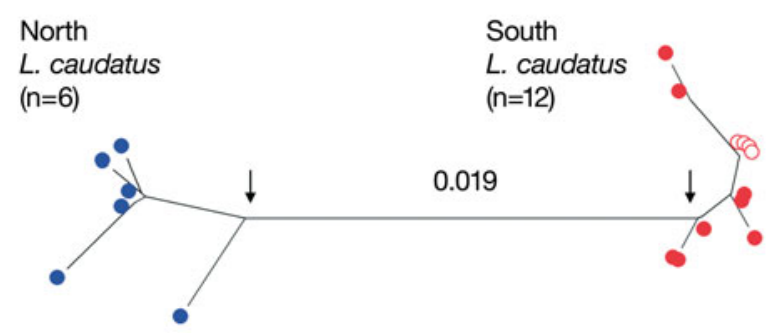

Fig. 3. Unrooted neighbour-joining tree of K2P distances from Lepidopus caudatus from the northern Atlantic (north, in blue) and southern waters (south: red; Australia and New Zealand: closed circles; South Africa: open circles. Distance between arrowed points given 


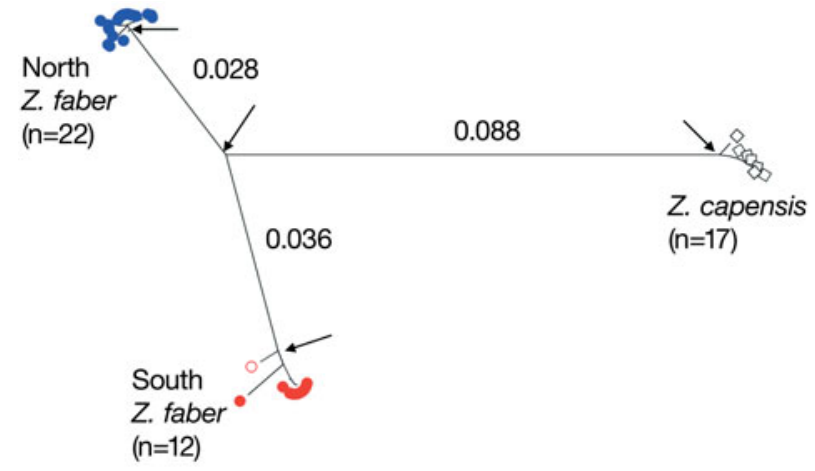

Fig. 4. Unrooted neighbour-joining tree of K2P distances from Zeus faber from the northern Atlantic (including Mediterranean) (north, in blue) and southern waters (south: red; Australia and New Zealand: closed circles; South Africa: open circles and Z. capensis: open rectangles). Distances between arrowed points given

the 3 species with $\mathrm{N}-\mathrm{S}$ differentiation (2 of which may well include currently unrecognised species, see below) are excluded. Lepidopus caudatus and Zeus faber have exceptionally high intraspecies divergences, more akin to congeneric than conspecific levels. Congeneric levels for 207 species of teleosts and chondrichthyans and 210 species of chondrichthyans averaged about 9.9 and $7.5 \%$, respectively (Ward et al. 2005, 2008).

Hebert et al. (2004b) suggested that genetically divergent specimens could be flagged as provisional species if they showed 10 -fold the mean intraspecific differentiation for the group under study. With such a definition, Lepidopus caudatus would not qualify for provisional species status, although Zeus faber would, with ease. However, almost $20 \%$ of the comparisons among congeneric fish species have distances of $<2 \%$ (Ward et al. 2005), so a distance between groups of nearly $3 \%$ certainly does not rule out the 2 L. caudatus clades as different species. In fact, samples of $L$. caudatus from Southwest Africa and the North Atlantic (Azores) differ significantly in dorsal fin pigmentation and meristics (Mikhailin 1977, Nakamura \& Parin 1993). Thus, there is both genetic and non-genetic evidence that these might indeed be different species. The north and south 'species' of L. caudatus are both deeply divergent (distance of ca. $20 \%$ ) from the only other Lepidopus barcoded thus far, the crested scabbardfish L. altifrons (data not shown).

With respect to Zeus faber, the ocellated John dory from Australia was initially termed Z. australis Richardson, and ocellated specimens from Japan, South Africa and New Zealand have often been referred to as Z. japonicus Valenciennes (see Heemstra 1980). However, Heemstra (1980) could not find any reliable characters to separate these species and concluded that all such descriptions referred to a single, widely distributed species, Z. faber. The DNA barcode does reliably discriminate northern and southern specimens; Japanese specimens await COI sequencing. Interestingly, 3 Japanese individuals did differ from 2 Atlantic Ocean/Mediterranean individuals by about $9 \%$ for cytochrome $b$, consistent with these 2 groups corresponding to 2 species (Teletchea et al. 2008), but South African individuals await cytochrome $b$ sequencing. The north and south 'species' of $Z$. faber separate from their only other congener, the Cape dory Z. capensis, by a COI genetic distance of about $12 \%$ (Fig. 4).

We therefore suggest that Lepidopus caudatus and Zeus faber each refer to 2 distinct biological species, one restricted to northern waters and the other restricted to southern waters. Whether or not Japanese specimens of Zeus faber are specifically similar to or distinct from those in southern waters awaits clarification. These taxa require further examination by expert taxonomists. This is likely to necessitate extensive morphological and meristic analyses from individuals from different parts of their range, ideally backed-up with nuclear DNA analyses. Both are commercially important species, and their species status needs to be settled.

DNA barcoding continues to stimulate debate (e.g. Costa \& Carvalho 2007, and comments in the same issue), but its utility in generating robust molecular criteria for species identification and resolution, at all life-history stages, provides a valuable extension to the Linnaean system.

Acknowledgements. We thank colleagues for donating unpublished barcodes for this study: M. Gomon (Victoria Museum, Melbourne) and M. McGrouther (Australian Museum, Sydney) for the southern Halosauropsis macrochir and Pseudotriakis microdon, respectively; P. Bentzen and S. Clifford (Dalhousie University) and E. Kenchington (Department of Fisheries and Oceans, Canada) for most of the northern Atlantic Prionace glauca and Isurus oxyrinchus; P. Smith (NIWA, New Zealand) for some southern specimens of Isurus oxyrinchus, Etmopterus pusillus, Squalus acanthias and Tetragonurus cuvieri; and Tyler Zemlak (Dalhousie University) and Alan Connell (SAIAB, South Africa) for the South African Zeus faber, Z. capensis and Lepidopus caudatus. We thank those who helped with collections and/or identifications, including, from Australia and New Zealand, P. Last, G. Yearsley, A. Graham, W. White (CSIRO Hobart) and P. Smith, and, from the North Atlantic, I. Byrkjedal and E. Willasen (University of Bergen, Norway), F. Porteiro (University of the Azores, Portugal), T. Sutton (Harbor Branch Oceanographic Institution, Florida), M. Dimech (MCFS, Malta), R. Martins and A. dos Santos (IPIMAR, Portugal), M. Esmeralda Costa (University of Algarve, Portugal), J. Alves (Museu Bocage, Portugal), M. H. Costa (IMAR, Portugal), N. Tysklind and B. Gilbert (Bangor University, UK). R. Hanner, N. Ivanova and T. Zemlak (University of Guelph, Canada) assisted with the molecular analyses. G. Carvalho and M. Alexandrou (Bangor University) assisted with laboratory 
facilities and data analyses, respectively. We thank W. White and 5 anonymous referees for useful comments leading to an improved manuscript. F.O.C. was supported by a Marie Curie Fellowship (EC Contract No: MEIF-CT-2005-024966). D.S. was supported through funding to the Canadian Barcode of Life Network from Genome Canada through the Ontario Genomics Institute.

\section{LITERATURE CITED}

Barrett RDH, Hebert PDN (2005) Identifying spiders through DNA barcodes. Can J Zool 83:481-491

Campana SE, Marks L, Joyce W (2005) The biology and fishery of shortfin mako sharks (Isurus oxyrinchus) in Atlantic Canadian waters. Fish Res 73:341-352

> Casey JG, Kohler NE (1992) Tagging studies on the shortfin mako shark (Isurus oxyrinchus) in the western North Atlantic. Aust J Mar Freshwater Res 43:45-60

Clare EL, Lim BK, Engstrom MD, Eger JL, Hebert PDN (2007) DNA barcoding of neotropical bats: species identification and discovery within Guyana. Mol Ecol Notes 7:184-190

Clarke MR, Stevens JD (1974) Cephalopods, blue sharks and migration. J Mar Biol Assoc UK 54:949-957

Costa FO, Carvalho GR (2007) The Barcode of Life Initiative: synopsis and prospective societal impacts of DNA barcoding of fish. Genomics Soc Policy 3:29-40

Costa FO, deWaard JR, Boutillier J, Ratnasingham S, Dooh RT, Hajibabaei M, Hebert PDN (2007) Biological identifications through DNA barcodes: the case of the Crustacea. Can J Fish Aquat Sci 64:272-295

Dasmahapatra KK, Mallet J (2006) DNA barcodes: recent successes and future prospects. Heredity 97:254-255

Elliott NG, Smolenski AJ, Ward RD (1994) Allozyme and mitochondrial DNA variation in orange roughy, Hoplostethus atlanticus (Teleostei: Trachichthyidae): little differentiation between Australian and North Atlantic populations. Mar Biol 119:621-627

Excoffier L, Laval G, Schneider S (2005) Arlequin ver. 30: an integrated software package for population genetics data analysis. Evol Bioinform Online 1:47-50

> Hebert PDN, Cywinska A, Ball SL, deWaard JR (2003) Biological identifications through DNA barcodes. Proc R Soc Lond B Biol Sci 270:313-322

Hebert PDN, Penton EH, Burns JM, Janzen DH, Hallwachs W (2004a) Ten species in one: DNA barcoding reveals cryptic species in the neotropical skipper butterfly Astraptes fulgerator. Proc Natl Acad Sci USA 101:14812-14817

Hebert PDN, Stoeckle MY, Zemlak TS, Francis CM (2004b) Identification of birds through DNA barcodes. PLoS Biol 2:1657-1663

Heemstra PC (1980) A revision of the zeid fishes (Zeiformes: Zeidae) of South Africa. Ichthyol Bull JLB Smith Inst Ichthyol 41:1-18

Hoarau G, Borsa P (2000) Extensive gene flow within sibling species in the deep-sea fish Beryx splendens. CR Acad Sci Paris 323:315-325

Editorial responsibility: Asbjørn Vøllestad, Oslo, Norway
Ivanova NV, Zemlak TS, Hanner RH, Hebert PDN (2007) Universal primer cocktails for fish DNA barcoding. Mol Ecol Notes 7:544-548

> Kimura M (1980) A simple method of estimating evolutionary rate of base substitutions through comparative studies of nucleotide sequences. J Mol Evol 16:111-120

> Kumar S, Tamura K, Nei M (2004) MEGA3: integrated software for molecular evolutionary genetics analysis and sequence alignment. Brief Bioinform 5:150-163

Mikhailin SV (1977) The intraspecific variability of the frostfish, Lepidopus caudatus. Vopr Ikhtiol 17:226-236 (in Russian)

Moritz C, Cicero C (2004) DNA barcoding: promise and pitfalls. PLoS Biol 2:1529-1531

Nakamura I, Parin NV (1993) FAO species catalogue, Vol 15. Snake mackerels and cutlassfishes of the world (families Gempylidae and Trichiuridae). Food and Agriculture Organization of the United Nations, Rome

Queiroz N, Lima FP, Maia A, Ribeiro PA, Correia JP, Santos AA (2005) Movement of blue shark, Prionace glauca, in the north-east Atlantic based on mark-recapture data. J Mar Biol Assoc UK 85:1107-1112

> Ratnasingham S, Hebert PDN (2007) BOLD: the Barcode of Life Data System (www.barcodinglife.org). Mol Ecol Notes $7: 355-364$

Rock J, Costa FO, Walker DI, North AW, Hutchinson WF, Carvalho GR (2008) DNA barcoding of fish of the Antarctic Scotia Sea indicate priority groups for taxonomic and systematic focus. Antarct Sci 20:253-262

> Smith PJ (1986) Genetic similarity between samples of the orange roughy Hoplostethus atlanticus from the Tasman Sea, south-west Pacific Ocean and the north-east Atlantic Ocean. Mar Biol 91:173-180

Smith MA, Fisher BL, Hebert PDN (2005) DNA barcoding for effective biodiversity assessment of a hyperdiverse arthropod group: the ants of Madagascar. Philos Trans R Soc Lond B 360:1825-1834

Tamura K, Nei M, Kumar S (2004) Prospects for inferring very large phylogenies by using the neighbor-joining method. Proc Natl Acad Sci USA 101:11030-11035

Teletchea F, Bernillon J, Duffraisse M, Laudet V, Hänni C (2008) Molecular identification of vertebrate species by oligonucleotide microarray in food and forensic samples. J Appl Ecol 45:967-975

Ward RD, Skibinski DOF, Woodwark M (1992) Protein heterozygosity, protein structure, and taxonomic differentiation. Evol Biol 26:73-159

> Ward RD, Woodwark M, Skibinski DOF (1994) A comparison of genetic diversity levels in marine, freshwater and anadromous fish. J Fish Biol 44:213-232

Ward RD, Zemlak TS, Innes BH, Last PR, Hebert PDN (2005) Barcoding Australia's fish species. Philos Trans R Soc Lond B 360:1847-1857

Ward RD, Holmes BH, White WT, Last PR (2008) DNA barcoding Australasian chondrichthyans: results and potential uses in conservation. Mar Freshw Res 59:57-71

Submitted: February 22, 2008; Accepted: June 4, 2008

Proofs received from author(s): July 8, 2008 